\title{
MARINE RESERVOIR CORRECTIONS FOR THE INDIAN OCEAN AND SOUTHEAST ASIA
}

\begin{abstract}
John Southon $^{1} \bullet$ Michaele Kashgarian $^{2} \bullet$ Michel Fontugne $^{3} \bullet$ Bernard Metivier $^{4} \bullet$ Wyss W-S Yim ${ }^{5}$
ABSTRACT. We have measured radiocarbon in prebomb known-age shells and coral from the Indian Ocean and southeast Asia to determine marine reservoir age corrections. Western Indian Ocean results show a strong ${ }^{14} \mathrm{C}$ depletion due to upwelling in the Arabian Sea, and indicate that this signal is advected over a wide area to the east and south. In contrast, the surface waters of the South China Sea contain relatively high levels of ${ }^{14} \mathrm{C}$, due in part to the input of well-equilibrated water masses from the western Pacific. The easternmost regions of the Indian Ocean are also strongly influenced by the flowthrough of Pacific waters north of Australia.
\end{abstract}

\section{INTRODUCTION}

Dissolved inorganic carbon (DIC) in the surface ocean (the mixed layer) is influenced by exchange with both the atmosphere and the radiocarbon-depleted deep ocean (Stuiver and Ostlund 1983) and has a ${ }^{14} \mathrm{C}$ content intermediate between the two. A knowledge of the resulting surface ocean ${ }^{14} \mathrm{C}$ age offset relative to that of atmospheric $\mathrm{CO}_{2}$ - the reservoir age-is essential for dating marine materials. Stuiver and co-workers (Stuiver et al. 1986; Stuiver and Brazuinas 1993; Stuiver et al. 1998) have used a carbon reservoir model to generate a global marine ${ }^{14} \mathrm{C}$ age calibration $\mathrm{R}(\mathrm{t})$ that incorporates temporal variations forced by known changes in atmospheric ${ }^{14} \mathrm{C}$. This calibration is extended through additional regional corrections ( $\Delta \mathrm{R}$ values) for spatial variations in upwelling, water mass mixing, and air-sea gas exchange. Typically, these corrections are determined by dating prebomb known-age marine carbonate.

Prebomb ${ }^{14} \mathrm{C}$ data for the Indian Ocean and adjacent marginal seas are relatively sparse. Broecker (1963) measured ${ }^{14} \mathrm{C}$ depletions of $-70 \%$ and $-59 \%$ in shells collected near Mombasa and north of Bombay (no collection dates or ${ }^{14} \mathrm{C}$ uncertainties given). Other early measurements include data on shells (Gillespie 1977; Rhodes 1980; Delibrias 1980; Bowman 1985) and coral bands (Broecker et al. 1987; Cember 1989; Toggweiler et al. 1991). In recent work, von Rad et al. (1999) measured ${ }^{14} \mathrm{C}$ in known-age forams from varved sediment cores recovered off Pakistan, and Dutta et al. (2001) dated mollusks to determine reservoir ages for seven sites in the Arabian Sea and Bay of Bengal. We know of no published reservoir age data for southeast Asia, though Konishsi et al. (1982) measured ${ }^{14} \mathrm{C}$ time series in two coral heads from Okinawa to the northeast. In this study, we present ${ }^{14} \mathrm{C}$ data from known-age mollusk, gastropod, and coral samples from sites between the Cape of Good Hope and the western Pacific, primarily from the western Indian Ocean and the South China Sea. We discuss these results within the framework of the regional oceanography of the Indian Ocean and southeast Asia.

\section{RADIOCARBON AGE DETERMINATIONS}

Prebomb mollusk and gastropod samples for this study are from the collections of the Museum National d'Histoire Naturelle, Paris (MNHN) and the US National Museum of Natural History, Smithsonian Institution, Washington, DC (USNM). Post-bomb samples were obtained from the

\footnotetext{
${ }^{1}$ Earth System Science Department, 220 Rowland Hall, University of California, Irvine, California, 92697-3100, USA. Email: jsouthon@uci.edu.

${ }^{2}$ Center for AMS, L-397, Lawrence Livermore National Laboratory, Livermore, California 94551-9900 USA

${ }^{3}$ Laboratoire des Sciences, du Climat et de l'Environment, Domaine du CNRS, F-91198 Gif-sur-Yvette Cedex, France

${ }^{4}$ Laboratoire de Biologie des Invertebres Marins et Malacologie, Musuem National d'Histoire Naturelle, 55 Rue de Buffon, 75005 Paris, France

${ }^{5}$ Department of Earth Sciences, The University of Hong Kong, Pokfulam Road, Hong Kong SAR, China
} 
Hong Kong Museum of History (H), and an approximately 100-year-old Porites coral head from the Xisha Islands in the South China Sea was provided by Dr Min Sun of the University of Hong Kong. Samples include MNHN specimens from as early as 1820 (no known-age specimens collected earlier were available, as all records of the French Royal collection were lost during the French Revolution). Documentation included species identification, sampling date or date of entry into the collection, and location, though only regional geographical information (e.g., "Ceylon", "Red Sea") was available in some cases. Some early USNM samples are known to have been collected prior to the dates indicated, but probably by only a few decades at most. For the purposes of this study, we have assumed that the sampling and collection entry dates are equivalent.

The shells were cleaned by washing and grinding the surface. Aliquots a few $\mathrm{mm}$ square-large enough to cover at least one entire year of growth-were taken from near the outer (growing) edge of each shell. The carbonate was crushed to a $0.5-1 \mathrm{~mm}$ powder, etched with $0.1 \mathrm{~N} \mathrm{HCl}$ to remove $30 \%$ of each sample, and subsamples of $10-15 \mathrm{mg}$ were hydrolyzed to $\mathrm{CO}_{2}$ with $85 \%$ phosphoric acid. Calcite blanks were also measured, and duplicate aliquots of several samples were prepared and measured. The $\mathrm{CO}_{2}$ samples were converted to graphite by hydrogen reduction with an iron or cobalt catalyst (Vogel et al. 1987; Loyd et al. 1991), and ${ }^{14} \mathrm{C}$ was measured at the Center for AMS, LLNL (Southon et al. 1990). Bands from coral slabs were sampled with a Dremel ${ }^{\circledR}$ milling tool and the carbonate powder was treated as above. Separate aliquots were taken for $\delta^{13} \mathrm{C}$ measurements, or values of $0 \%$ (mollusks/gastropods) or $-2 \%$ (Porites coral) were assumed based on measured values for other samples.

\section{RESULTS AND DISCUSSION}

Indian Ocean ${ }^{14} \mathrm{C}$ and stable isotope results are presented in Table 1 . The difference between the conventional ${ }^{14} \mathrm{C}$ age for each sample (Stuiver and Polach 1977) and the model age for the calender year of collection (Stuiver and Braziunas 1993) gives the $\Delta \mathrm{R}$ corrections, and the uncertainties are assumed to be those of the age determinations. (Note that small offsets appear between the 1986, 1993 and 1998 marine ${ }^{14} \mathrm{C}$ calibrations due to minor changes in model parameters and slight differences in the atmospheric datasets used as model input, but these are negligible compared to ${ }^{14} \mathrm{C}$ measurement uncertainties and natural $\Delta \mathrm{R}$ variability.) The results are also given as $\Delta^{14} \mathrm{C}$, corrected for radioactive decay between the year of collection and AD 1950. An additional correction has also been applied to the $\Delta^{14} \mathrm{C}$ data for the 20th century Suess effect- the ${ }^{14} \mathrm{C}$ dilution due to fossil fuel $\mathrm{CO}_{2}$ uptake by the oceans (Druffel and Suess 1983; Stuiver and Braziunas 1993; see Table 1 footnote) - but note that this is simply an estimate and the actual effect may be more complex and variable (Druffel and Griffin 1993; Druffel 1997).

\section{Indian Ocean}

$\Delta \mathrm{R}$ values are high in almost all of the western Indian Ocean samples, but a 1959 sample from Mauritius shows a negative $\Delta R$, an artifact of bomb ${ }^{14} \mathrm{C}$ uptake in the late 1950s. A sample from Pondicherry in the western Bay of Bengal gave an extremely high $\Delta \mathrm{R}$ of 495 years, in strong disagreement with our result from the Nicobar Islands and the Bay of Bengal data of Dutta et al. (2001). The rather low $\delta^{13} \mathrm{C}$ value of $-1.9 \%$ o for the Pondicherry sample, suggestive of fresh water influence, may indicate that this anomalous result is due to geological carbonate input.

Omitting the two outliers and eastern Indian Ocean data from Java, Australia, and the Bay of Bengal discussed below, the results cluster closely around a mean $\Delta \mathrm{R}$ of $158 \pm 68$ years $(\mathrm{N}=31)$ (Figure 1), or $\Delta{ }^{14} \mathrm{C}$ (Suess-corrected) $=-67.3 \pm 8.1 \%$. The \pm 68 -year $1-\sigma$ scatter in the data set is only slightly larger than the uncertainties in the individual results, typically \pm 55 years. This suggests that a rough 
Table 1 Prebomb radiocarbon data from this study_-Indian Ocean

\begin{tabular}{|c|c|c|c|c|c|c|c|c|c|c|c|c|c|}
\hline $\begin{array}{l}\text { Sample nrs } \\
(\text { CAMS\# })^{\mathrm{a}}\end{array}$ & Museum nr & $\begin{array}{l}\text { Species (b=bivalve, } \mathrm{c}=\text { coral, } \\
\mathrm{g}=\text { gastropod) }\end{array}$ & $\begin{array}{l}\text { Coll. } \\
\text { date }\end{array}$ & Location & $\begin{array}{l}\text { Lat } \\
\left({ }^{\circ} \mathrm{N}\right)\end{array}$ & $\begin{array}{l}\text { Long } \\
\left({ }^{\circ} \mathrm{E}\right)\end{array}$ & $\begin{array}{l}\delta^{13} \mathrm{C} \\
(\% \circ)\end{array}$ & $\begin{array}{l}\Delta^{14} \mathrm{C} \\
(\% \circ)\end{array}$ & \pm & $\begin{array}{l}\Delta^{14} \mathrm{C} \\
\text { (Suess } \\
\text { corr. }^{\mathrm{b}}\end{array}$ & $\begin{array}{l}{ }^{14} \mathrm{C} \text { age } \\
\pm \mathrm{BP}\end{array}$ & $\begin{array}{l}\text { Model } \\
\text { age } \\
\text { (BP) }\end{array}$ & $\Delta \mathrm{R}$ \\
\hline \multicolumn{14}{|c|}{ Western Arabian Sea } \\
\hline 3953 & MNHN-C28 & Marcia flammea (b) & 1843 & Muscat & 23.5 & 58.6 & 1.8 & -81.4 & 5.8 & -81.4 & $786 \pm 51$ & 501 & 285 \\
\hline 3920 & MNHN-C1 & Marcia flammea (b) & 1850 & Aden & 12.5 & 45 & 1.5 & -66.9 & 6.6 & -66.9 & $653 \pm 57$ & 496 & 157 \\
\hline 3926 & MNHN-C7 & Gafrarium callipygum (b) & 1850 & Socotra & 12.5 & 54 & 0.6 & -72.5 & 6.6 & -72.5 & $702 \pm 57$ & 496 & 206 \\
\hline 3929 & MNHN-C10 & Pinctada margaritifera $(b)$ & 1897 & Muscat & 23.5 & 58.6 & 1.7 & -72.7 & 6.9 & -72.7 & $658 \pm 60$ & 469 & 189 \\
\hline 3938 & MNHN-C17 & Irus rugosus (b) & 1920 & Perim & 12.5 & 53.3 & 1.8 & -64.7 & 6.6 & -62.7 & $566 \pm 57$ & 465 & 101 \\
\hline $3948+3960$ & MNHN-C23 & Marcia flammea (b) & 1921 & Aden & 12.5 & 45 & 1.2 & -86.3 & 5.8 & -84.3 & $753 \pm 51$ & 466 & 287 \\
\hline 3921 & MNHN-C2 & Pinctada radiata $(b)$ & 1921 & Aden & 12.5 & 45 & 1.7 & -76.5 & 7.8 & -74.5 & $668 \pm 68$ & 466 & 202 \\
\hline 3924 & MNHN-C5 & Tapes deshayesi (b) & 1921 & Djibouti & 11.3 & 43 & 2.4 & -64.0 & 6.6 & -62.0 & $559 \pm 57$ & 466 & 93 \\
\hline \multicolumn{14}{|c|}{ Red Sea/Persian Gulf } \\
\hline $3939+3944$ & MNHN-C18 & Pinctada radiata (b) & 1839 & Red Sea ${ }^{c}$ & ca. 20 & ca. 38 & 1.7 & -59.5 & 4.5 & -59.5 & $600 \pm 38$ & 504 & 96 \\
\hline 3958 & MNHN-C33 & Pinctada radiata $(b)$ & 1952 & Dohar, Qatar & 25.3 & 51.4 & 1.8 & -77.9 & 6.0 & -67.9 & $649 \pm 53$ & 486 & 163 \\
\hline \multicolumn{14}{|c|}{ Eastern Arabian Sea/Sri Lanka } \\
\hline 3928 & MNHN-C9 & Marcia recens (b) & 1836 & Bombay & 18.8 & 72.7 & 0.2 & -65.7 & 6.6 & -65.7 & $656 \pm 57$ & 505 & 151 \\
\hline 8693 & USNM-90558 & Gastropod & $1887^{\mathrm{d}}$ & Bombay & 18.9 & 72.8 & 0 & -62.4 & 5.5 & -62.4 & $580 \pm 50$ & 473 & 107 \\
\hline 3950 & MNHN-C25 & Marcia opima $(b)$ & 1841 & Goa, India & 16.5 & 73.8 & -1.1 & -76.2 & 5.8 & -76.2 & $742 \pm 51$ & 502 & 240 \\
\hline $3927+3933$ & MNHN-C8 & Paphia textile (b) & 1847 & Malabar, India & 11.3 & 76 & 0.6 & -63.2 & 7.5 & -63.2 & $625 \pm 64$ & 499 & 126 \\
\hline $3940+3945$ & MNHN-C19 & Pinctada margaritifera $(b)$ & 1841 & Sri Lanka ${ }^{c}$ & ca. 7 & ca. 80 & 2.2 & -58.6 & 5.5 & -58.6 & $591 \pm 47$ & 502 & 89 \\
\hline 3947 & MNHN-C22 & Pinctada radiata $(b)$ & 1874 & Sri Lanka ${ }^{c}$ & ca. 7 & ca. 80 & 1.1 & -70.8 & 6.2 & -70.8 & $663 \pm 53$ & 484 & 179 \\
\hline 3959 & MNHN-C34 & Timoclea cochinensis (b) & 1924 & Sri Lanka ${ }^{c}$ & ca. 7 & ca. 80 & 0.3 & -74.7 & 6.0 & -74.7 & $649 \pm 53$ & 465 & 184 \\
\hline 8692 & USNM-89612 & Gastropod & $1887^{\mathrm{b}}$ & Sri Lanka ${ }^{c}$ & ca. 7 & ca. 80 & 0 & -56.1 & 5.5 & -56.1 & $530 \pm 50$ & 473 & 57 \\
\hline $3957+3962$ & MNHN-C32 & Gafrarium scriptum (b) & 1841 & Raffles Bay, N.Australia & -11.3 & 132.4 & 0.4 & -53.6 & 4.7 & -53.6 & $549 \pm 40$ & 502 & 47 \\
\hline
\end{tabular}

${ }^{\mathrm{a}}$ CAMS = Center for AMS, LLNL; MNHN = Museum National d'Histoire Naturelle; USNM = National Museum of Natural History, Smithsonian Institution.

${ }^{b}$ Estimated marine fossil fuel (Suess) effect, per mil: 1959: $-16 \pm 4 ; 1952:-10 \pm 2 ; 1945$ : $-8 \pm 2 ; 1925$ : $-2 \pm 2 ; 1920$ : $-2 \pm 2$; pre-1920: ca. zero.

${ }^{\mathrm{c}}$ Location approximate

${ }^{\mathrm{d}}$ Collected earlier, assumed this date for calculations 
Table 1 Prebomb radiocarbon data from this study-Indian Ocean $(\text { Continued })^{\text {a }}$

\begin{tabular}{|c|c|c|c|c|c|c|c|c|c|c|c|c|c|}
\hline $\begin{array}{l}\text { Sample nrs } \\
\text { (CAMS\#) }\end{array}$ & Museum\# & $\begin{array}{l}\text { Species (b=bivalve, } \mathrm{c}=\text { coral, } \\
\mathrm{g}=\text { gastropod) }\end{array}$ & $\begin{array}{l}\text { Coll. } \\
\text { date }\end{array}$ & Location & $\begin{array}{l}\text { Lat } \\
\left({ }^{\circ} \mathrm{N}\right)\end{array}$ & $\begin{array}{l}\text { Long } \\
\left({ }^{\circ} \mathrm{E}\right)\end{array}$ & $\begin{array}{l}\delta^{13} \mathrm{C} \\
(\% \circ)\end{array}$ & $\begin{array}{l}\Delta^{14} \mathrm{C} \\
(\% o)\end{array}$ & \pm & $\begin{array}{l}\Delta^{14} \mathrm{C} \\
\text { (Suess } \\
\text { corr.) }\end{array}$ & $\begin{array}{l}{ }^{14} \mathrm{C} \text { age } \\
\pm \mathrm{BP}\end{array}$ & $\begin{array}{l}\text { Model } \\
\text { age } \\
\text { (BP) }\end{array}$ & $\Delta \mathrm{R}$ \\
\hline \multicolumn{14}{|c|}{ Southwest tropical Indian Ocean } \\
\hline $3930+3942$ & MNHN-C11 & Tapes deshayesi (b) & 1836 & Ile de France, Mauritius & -21 & 56 & 1.2 & -60.9 & 4.7 & -60.9 & $616 \pm 40$ & 505 & 111 \\
\hline $3922+3932$ & MNHN-C3 & Laevicardium flavum $(b)$ & 1945 & Mauritius & -21 & 56 & 0.6 & -69.3 & 4.9 & -61.3 & $582 \pm 42$ & 480 & 102 \\
\hline 3946 & MNHN-C21 & Pinctada margaritifera $(b)$ & $1959^{\mathrm{e}}$ & Mauritius & -21 & 56 & 1.7 & -51.8 & 6.7 & -35.8 & $418 \pm 57$ & 500 & -82 \\
\hline 3941 & MNHN-C20 & Pinctada radiata $(b)$ & 1841 & Diego-Suarez, Madagascar & -12.4 & 49.4 & 1.0 & -67.4 & 7.0 & -67.4 & $667 \pm 60$ & 502 & 165 \\
\hline 3935 & MNHN-C14 & Pinctada radiata $(b)$ & 1840 & Seychelles & -9.4 & 47 & 1.7 & -82.7 & 6.8 & -82.7 & $800 \pm 59$ & 503 & 297 \\
\hline 3936 & MNHN-C15 & Gafrarium pectinatum (b) & 1840 & Seychelles & -9.4 & 47 & 2.5 & -63.9 & 6.6 & -63.9 & $637 \pm 57$ & 503 & 134 \\
\hline 3949 & MNHN-C24 & Pinctada maculata (b) & 1840 & Seychelles & -9.4 & 47 & 0.0 & -56.9 & 6.7 & -56.9 & $577 \pm 57$ & 503 & 74 \\
\hline 3931 & MNHN-C12 & Fragum fragum $(b)$ & 1850 & Seychelles & -9.4 & 47 & 3.6 & -53.0 & 6.7 & -53.0 & $535 \pm 57$ & 496 & 39 \\
\hline 3954 & MNHN-C29 & Gafrarium pectinatum (b) & 1878 & Mahe, Seychelles & -9.4 & 47 & 0.8 & -66.7 & 7.2 & -66.7 & $624 \pm 62$ & 479 & 145 \\
\hline 3937 & MNHN-C16 & Tapes deshayesi $(b)$ & 1874 & Mayotte, Comoros & -13.1 & 45.7 & 2.1 & -62.8 & 6.6 & -62.8 & $595 \pm 57$ & 484 & 111 \\
\hline 3955 & MNHN-C30 & Laevicardium biradiatum (b) & 1921 & Comoros & -11.6 & 43.5 & 0.9 & -81.6 & 5.8 & -79.6 & $712 \pm 51$ & 466 & 246 \\
\hline $3934+3943$ & MNHN-C13 & Pinctada radiata $(b)$ & 1864 & Zanzibar & -6.3 & 39.3 & -0.1 & -65.7 & 4.6 & -65.7 & $630 \pm 40$ & 490 & 140 \\
\hline \multicolumn{14}{|c|}{ South Africa (E. coast) } \\
\hline 3925 & MNHN-C6 & Venerupis corrugatus $(b)$ & 1820 & Cape of Good Hope & -34.5 & 18.6 & 0.6 & -72.8 & 5.9 & -72.8 & $734 \pm 51$ & 522 & 212 \\
\hline 3951 & MNHN-C26 & Marcia paupercula $(b)$ & 1945 & Natal & -30 & 31.1 & 1.4 & -80.2 & 6.5 & -72.2 & $677 \pm 57$ & 480 & 197 \\
\hline \multicolumn{14}{|c|}{ Bay of Bengal } \\
\hline 3923 & MNHN-C4 & Marcia opima $(b)$ & $1920^{\mathrm{d}}$ & Pondicherry, India & 12.1 & 80 & -1.9 & -109.4 & 6.3 & -107.4 & $960 \pm 57$ & 465 & 495 \\
\hline 6574 & USNM-253450 & Thais sp. $(g)$ & $1913^{\mathrm{d}}$ & Nicobar Islands & 9 & 94 & 0 & -53.6 & 7.7 & -53.6 & $480 \pm 70$ & 463 & 17 \\
\hline \multicolumn{14}{|l|}{ Other } \\
\hline 6569 & USNM-260602 & Thais sp. (g) & 1910 & $\begin{array}{l}\text { Pelabuhanratu, } \\
\text { S. Java }\end{array}$ & -7.0 & 106.5 & 0 & -54.9 & 7.7 & -54.9 & $490 \pm 70$ & 462 & 28 \\
\hline $3957+3962$ & MNHN-C32 & Gafrarium scriptum (b) & 1841 & $\begin{array}{l}\text { Raffles Bay, } \\
\text { N.Australia }\end{array}$ & -11.3 & 132.4 & 0.4 & -53.6 & 4.7 & -53.6 & $549 \pm 40$ & 502 & 47 \\
\hline
\end{tabular}

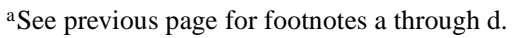

ePost-bomb 
upper limit for any regional $\Delta \mathrm{R}$ variations within the western Indian Ocean is $\sqrt{\left(68^{2}-55^{2}\right)}$, i.e., around \pm 40 years or $\pm 5 \%$. Since this value also provides an upper limit for any temporal changes, the results suggest that changes in western Indian Ocean reservoir ages over the period 1820-1950 are quite well described by the atmospheric forcing model: there are no indications of major changes in large-scale upwelling over this period.

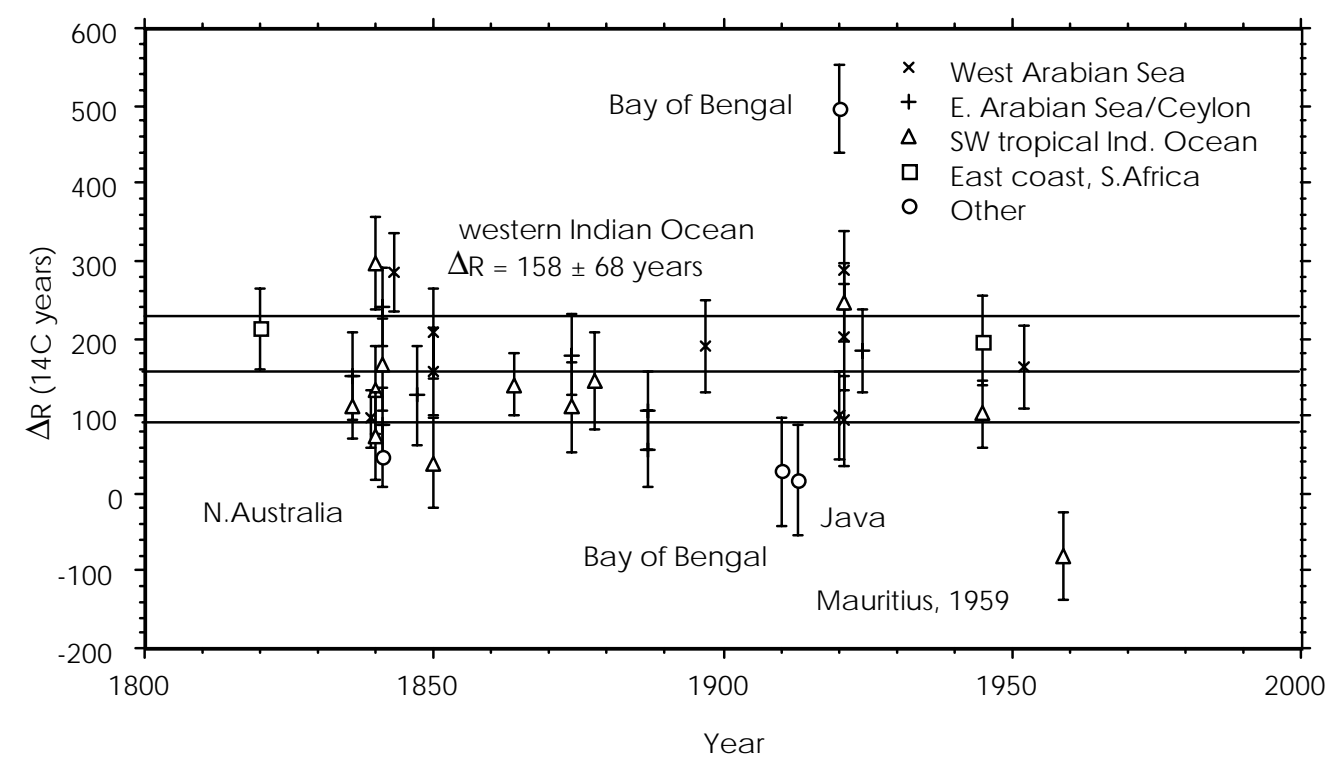

Figure $1 \Delta \mathrm{R}$ values from this study for the Indian Ocean and adjacent marginal seas, plotted against the year of collection. Apart from the five identified outliers (see text), the results show little variation above the scatter expected from the uncertainties in the radiocarbon measurements.

Table $2 \Delta{ }^{14} \mathrm{C}$ (Suess-corrected) and $\Delta \mathrm{R}$-regional means (this study)

\begin{tabular}{lcccc}
\hline Location & $\Delta^{14} \mathrm{C}(\% \circ)$ & \pm & $\Delta \mathrm{R}(\mathrm{yr})$ & \pm \\
\hline Indian Ocean & & & & \\
Western Arabian Sea (N=8) & -73.1 & 2.8 & 190 & 25 \\
Eastern Arabian Sea and Ceylon (N=8) & -66.0 & 2.6 & 140 & 20 \\
Tropical SW Indian Ocean (N=11) & -65.7 & 2.8 & 140 & 25 \\
East coast of South Africa (N=2) & -72.5 & 4.5 & 205 & 30 \\
South China Sea & & & & \\
South/central S. China Sea (N=10) & -47.4 & 2.3 & -25 & 20 \\
\hline
\end{tabular}

Regional mean $\Delta \mathrm{R}$ and Suess-corrected $\Delta{ }^{14} \mathrm{C}$ values for the western Indian Ocean are shown in Table 2. We have assumed that the values within each region are essentially constant, so that the relevant uncertainty is the standard error of the mean (i.e., $\sigma / \sqrt{\mathrm{N}}$ ). However, some results from within single regions do show substantial scatter; e.g., shells collected in the Seychelles in 1840 and 1850 show a 260 -year spread $(>4 \sigma)$ in reservoir age, and also show large $\delta^{13} C$ variations-see Table 1 . Whether this indicates real spatial variation within the local mixed layer, fast temporal changes, use of samples from lagoons or estuaries that do not reflect open ocean conditions, or some other cause, 
is unclear. It is important to remember when evaluating shell dates that such variations do exist (see also Bhushan et al. 1994; Ingram and Southon 1996; Dye 1995) and that the causes are not always obvious, so that use of regional $\Delta \mathrm{R}$ values may gloss over substantial variability.

Data from previous studies are summarized in Table 3 and synthesized with our own results in Figure 2. The overall agreement between the different datasets is generally good, though a few clear exceptions exist. A lack of concordance between our results and data from Delibrias (1980) for Mauritius and Madagascar remains unresolved, but we note that Toggweiler et al. (1991) measured extremely variable post-bomb ${ }^{14} \mathrm{C}$ values in Mauritius corals, suggesting that perhaps prebomb ${ }^{14} \mathrm{C}$ levels in these waters also fluctuated. Data from Sri Lanka which also appear discordant are discussed below.

Table 3 Prebomb radiocarbon results from previous studies discussed in the text

\begin{tabular}{|c|c|c|c|c|c|c|c|}
\hline Reference & Location & $\begin{array}{l}\text { Lat } \\
\left({ }^{\circ} \mathrm{N}\right)\end{array}$ & $\begin{array}{l}\text { Long } \\
\left({ }^{\circ} \mathrm{E}\right)\end{array}$ & $\begin{array}{l}\Delta^{14} \mathrm{C}(\% \circ) \\
\text { (Suess-corr.) }\end{array}$ & \pm & $\begin{array}{l}\Delta \mathrm{R} \\
(\mathrm{yr})\end{array}$ & \pm \\
\hline Gillespie $(1977)^{\mathrm{a}}$ & $\begin{array}{l}\text { Garden Is., W Australia } \\
\text { Torres Str., Queensland (N=3) }\end{array}$ & $\begin{array}{l}-32.3 \\
-10\end{array}$ & $\begin{array}{l}115.7 \\
143\end{array}$ & $\begin{array}{l}-51.8 \\
-53.1\end{array}$ & $\begin{array}{l}10 \\
5.4\end{array}$ & $\begin{array}{l}5 \\
31\end{array}$ & $\begin{array}{l}80 \\
43\end{array}$ \\
\hline Rhodes et al. (1980) & Gulf of Carpentaria $(\mathrm{N}=2)$ & -12 & 142 & -54.2 & 3.9 & 41 & 70 \\
\hline Delibrias $(1980)^{b}$ & $\begin{array}{l}\text { Mauritius } \\
\text { Nossibe, NW Madagascar }\end{array}$ & $\begin{array}{l}-20.3 \\
-13.4\end{array}$ & $\begin{array}{l}57.5 \\
48.5\end{array}$ & $\begin{array}{l}-47.2 \\
-41.5\end{array}$ & $\begin{array}{l}4 \\
4\end{array}$ & $\begin{array}{l}-40 \\
-49\end{array}$ & $\begin{array}{l}35 \\
35\end{array}$ \\
\hline Konishi et al. (1982) & Okinawa $(\mathrm{N}=18)$ & 26.4 & 127.8 & -32.8 & 0.9 & -149 & 7 \\
\hline Bowman (1985) & NW Australiac $(\mathrm{N}=7)$ & 17 & 123 & -58.9 & 4.4 & 44 & 46 \\
\hline Broecker et al. $(1987)^{\mathrm{d}}$ & Al-Jurayd Is, Persian Gulf & 27.2 & 49.9 & -68 & 8.2 & 179 & 66 \\
\hline Cember (1989) & $\begin{array}{l}\text { Hurghada, Red Sea }(\mathrm{N}=2) \\
\text { Port Sudan, Red Sea }(\mathrm{N}=2)\end{array}$ & $\begin{array}{l}27 \\
20\end{array}$ & $\begin{array}{l}34 \\
37\end{array}$ & $\begin{array}{l}-65.9 \\
-65.5\end{array}$ & $\begin{array}{l}5.3 \\
5.7\end{array}$ & $\begin{array}{l}135 \\
132\end{array}$ & $\begin{array}{l}42 \\
45\end{array}$ \\
\hline Toggweiler et al. $(1991)^{d}$ & $\begin{array}{l}\text { Cocos-Keeling Is. } \\
\text { Djibouti }^{\mathrm{e}}\end{array}$ & $\begin{array}{l}-12 \\
11.3\end{array}$ & $\begin{array}{l}97 \\
43\end{array}$ & $\begin{array}{l}-71 \\
-67.8\end{array}$ & $\begin{array}{l}8.4 \\
8.5\end{array}$ & $\begin{array}{l}182 \\
147\end{array}$ & $\begin{array}{l}65 \\
68\end{array}$ \\
\hline von Rad et al. (1999) & Off Pakistan $(\mathrm{N}=2)$ & 24.83 & 65.92 & -77 & 2.2 & 218 & 20 \\
\hline Dutta et al. (2001) & $\begin{array}{l}\text { Gujarat }(\mathrm{N}=2) \\
\text { Chilika L., Orissa } \\
\text { Stewart Sd., Andaman Islands } \\
\text { Palk Bay, Tamilnadu }(\mathrm{N}=3)\end{array}$ & $\begin{array}{l}22.15 \\
19.8 \\
13 \\
9.2\end{array}$ & $\begin{array}{l}69 \\
85.5 \\
93 \\
79\end{array}$ & $\begin{array}{l}-67 \\
-39 \\
-51 \\
-52\end{array}$ & $\begin{array}{l}5 \\
7 \\
4.7 \\
2.7\end{array}$ & $\begin{array}{l}162 \\
-78 \\
-2 \\
20\end{array}$ & $\begin{array}{l}30 \\
53 \\
35 \\
20\end{array}$ \\
\hline
\end{tabular}

${ }^{\text {a }}$ Original data are $\delta^{14} \mathrm{C}: \Delta^{14} \mathrm{C}=\delta^{14} \mathrm{C}-\left(2 \times \delta^{13} \mathrm{C}+50\right) \times\left(1+\delta^{14} \mathrm{C} / 1000\right)$.

bOriginal data are "Apparent ages": radiocarbon ages calculated with 5730-yr half-life, with collection date 1950 subtracted. cCollection dates between 1902 and 1950, assume 1926.

${ }^{\mathrm{d}}$ Original data are $\mathrm{D}^{14} \mathrm{C}$, though quoted as $\Delta{ }^{14} \mathrm{C}$ : see Cember (1989)

${ }^{\mathrm{e}}$ Collection date pre-WWII, assume 1900.

The combined old and new data indicate that ${ }^{14} \mathrm{C}$ levels in western Indian Ocean surface waters are significantly low compared to the global surface water of the reservoir age model. In broad terms, this is consistent with known oceanographic data. GEOSECS results show that deep Indian Ocean water is strongly depleted in ${ }^{14} \mathrm{C}$ (Stuiver and Ostlund 1983), and vigorous upwelling of deep and bottom water is a feature of the large-scale northern Indian Ocean circulation (Toole and Warren 1993; Ganachaud and Wunsch 2000). In a more detailed view, the intense monsoon-driven upwelling which takes place off the Somali and southern Arabian coasts and to a lesser extent off Pakistan and India (Swallow 1984; Wyrtki 1973) is the basis for the large $\Delta \mathrm{R}$ values in the Arabian Sea. Several mechanisms combine to propagate the influence of this deep Indian Ocean water contribution not only throughout the Arabian Sea, but also into large areas of the western Indian Ocean and adjacent regions. 


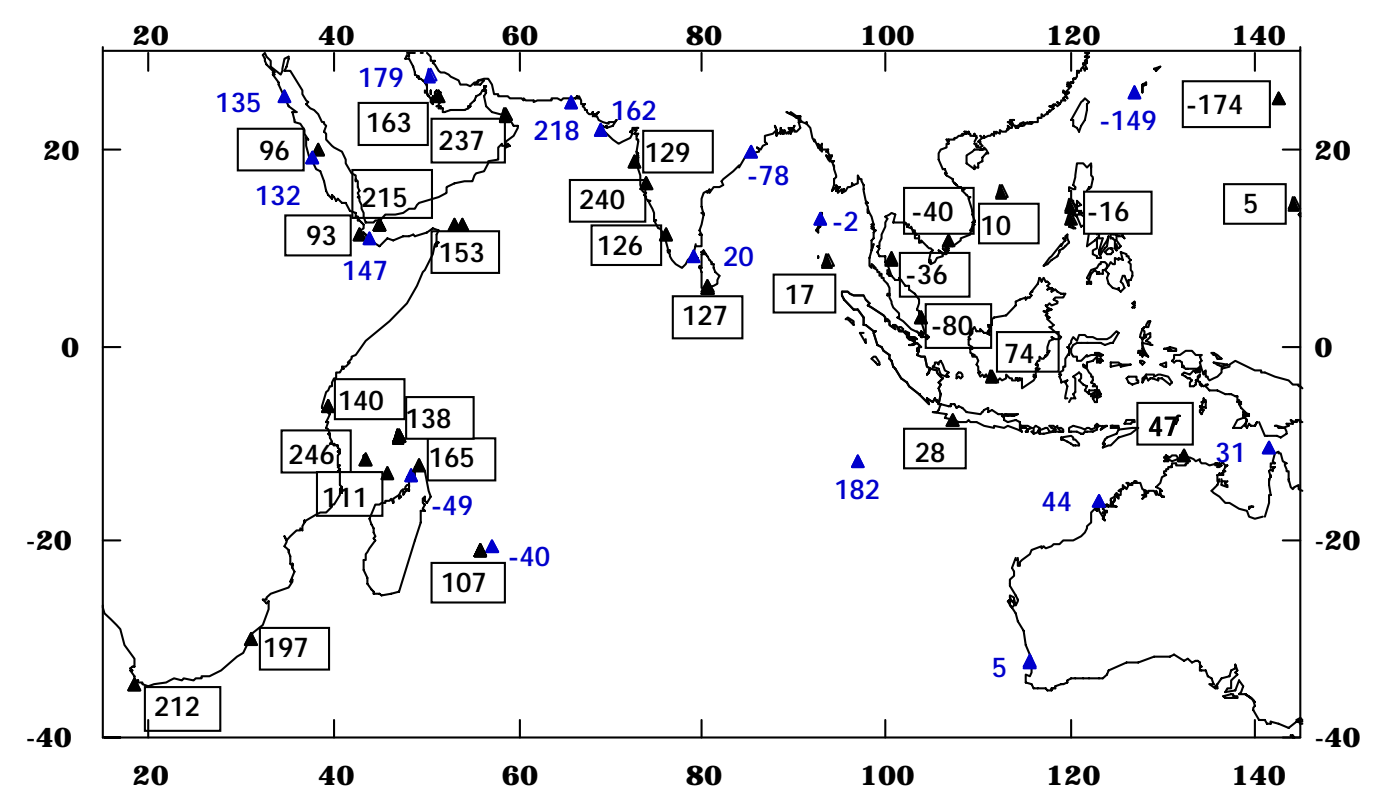

Figure 2 The geographic distribution of $\Delta \mathrm{R}$ values. Data shown in boxes are from this study. Others are selected results from previous investigations discussed in the text, converted from their original format (conventional ages, $\Delta^{14} \mathrm{C}$, etc.) to $\Delta \mathrm{R}$ values (Stuiver and Braziunas 1993). For clarity, some data have been grouped into local averages.

The circulations of the Persian Gulf and the Red Sea are characterized by surface inflow, increases in salinity (and therefore density) through evaporation and subsequent winter cooling, and outflow of water at depth (Cember 1989). The high $\Delta \mathrm{R}$ values in these marginal seas thus reflect those of the indrawn Arabian Sea surface water.

The northern and equatorial Indian Ocean circulation is particularly complex, with very large seasonal variations including reversals of major current systems occurring due to monsoon effects. However, in a simplified circulation scheme, the South Equatorial Current (SEC) effectively acts during the northern summer as a westward return flow south of the equator for water transported southeast from the Arabian Sea by the summer monsoon (Tchernia 1980; You 1997). The Arabian Sea gyre is then closed by northward flow along the African and Arabian coasts where the most intense upwelling occurs.

The high $\Delta \mathrm{R}$ values from Sri Lanka are consistent with this southeast transport of ${ }^{14} \mathrm{C}$-depleted Arabian Sea water, assuming our samples are from the south coast (exact locations are unknown). Dutta et al. (2001) measured much higher levels of ${ }^{14} \mathrm{C}$ in Sri Lankan samples, but those were from the shallow semi-enclosed waters of Palk Bay. This opens to the northeast on to the Bay of Bengal where they found low $\Delta \mathrm{R}$ values (supported by our Nicobar Islands result) due to density stratification from freshwater influence. The southeast flow from the Arabian Sea extends as far east as 80$100^{\circ} \mathrm{E}$ south of the equator (Tchernia 1980; You 1997), and thus may also influence the high reservoir age at Cocos-Keeling at $12^{\circ} \mathrm{S}, 97^{\circ} \mathrm{E}$ (Toggweiler et al. 1991).

The area around Mauritius, northern Madagascar, and the Seychelles lies in the path of the SEC. Hence the summer southeast flow from the Arabian Sea may contribute to the large $\Delta \mathrm{R}$ values in those regions also, by feeding into the eastern source regions of the SEC from the north. The winter monsoon reversal of the coastal Somali Current does not extend sufficiently far south to transport 
Arabian Sea water directly into the region (Schott et al. 1990), but does feed into the eastward flow of the Equatorial Counter Current, which retroflects south into the SEC off the Indonesian coast (Michida and Yoritaka 1996; You 1997). Equatorial upwelling undoubtedly also plays a part in bringing ${ }^{14} \mathrm{C}$-depleted water into the SEC, but this process is relatively weak in the Indian Ocean (Swallow 1984). The absence of a pronounced equatorial minimum in surface ${ }^{14} \mathrm{C}$ values in postbomb GEOSECS and INDIGO sections and the generally reduced spatial variability of ${ }^{14} \mathrm{C}$ north of $12^{\circ} \mathrm{S}$ (Stuiver and Ostlund 1983; Bard et al. 1989), further suggest the importance of advection around the northern circulation relative to upwelling along its southern edge.

Water from this region north of Madagascar is transported south, via the East Mozambique Current in the east and through the Mozambique Channel in the west, into the southwest trending Aguhlas Current which retroflects eastward south of the Cape of Good Hope. The large reservoir ages along the east coast of South Africa (Natal, Cape of Good Hope) are nevertheless surprising, as more than $80 \%$ of the Aguhlas flow comes from further east (Stramma and Lutjeharms 1997), from recirculation south of Madagascar and from the South Indian Ocean subtropical gyre where post-bomb ${ }^{14} \mathrm{C}$ values are high (Stuiver and Ostlund 1983; Bard et al. 1989). However, hydrographic data suggest that the westernmost Aguhlas feeders have a strong influence on the inshore flow (Gordon 1986). If so, the large reservoir ages from South Africa may be due at least in part to the low ${ }^{14} \mathrm{C}$ content of the tropical source waters.

In contrast to the high $\Delta \mathrm{R}$ values from the western Indian Ocean, our samples from the south coast of Java (Pelabuhanratu) and northern Australia's Arnhem Land (Raffles Bay) gave low $\Delta \mathrm{R}$ values of $28 \pm 70$ and $47 \pm 40$ years, respectively. Previous results show $\Delta R=44 \pm 36$ years for northwestern Australia (Bowman 1985) and $\Delta \mathrm{R}=35 \pm 31$ years for Torres Strait (Gillespie 1977; Rhodes 1980). ${ }^{14} \mathrm{C}$ values in prebomb corals from Makassar Strait, Indonesia (M K, unpublished data) and the Coral Sea (Druffel and Griffin 1993, 1999) are equivalent to $\Delta \mathrm{R}$ close to zero. Thus, surface waters of the far western and southwestern Pacific are relatively well equilibrated with the atmosphere. Flow of these waters west through Torres Strait and south through the Indonesian Seaway (Gentilli 1972; Fieux et al. 1994; JGR 1996) gives low reservoir ages along the northwestern coast of Australia and the southern coasts of the eastern Indonesian Archipelago, but evidently does not extend as far west as Cocos-Keeling $\left(97^{\circ} \mathrm{E}\right)$. The poleward-flowing Leeuwin current (Gentilli 1972; Church et al. 1989) transports this well-equilibrated water mass along the west coast of Australia, affecting ${ }^{14} \mathrm{C}$ levels as far south as Garden Island in Western Australia at $32^{\circ} \mathrm{S}$ (Gillespie 1977).

Gordon (1986), Ganachaud and Wunsch (2000), and others have emphasized the importance of the warm-water route for the upper (return) limb of the global thermohaline circulation, via the Indian Ocean thermocline and the Aguhlas current (but see Schmitz [1995] for an opposing view). This return flow is associated with a ridge of minimum salinity extending westward in the thermocline from the region south of Timor to the African coast north of Madagascar (Gordon 1986; Fieux et al. 1996). The ${ }^{14} \mathrm{C}$ results from northern Australia constitute a surface signature of this movement of Pacific water west and south into the Timor Sea and beyond. However, the large ${ }^{14} \mathrm{C}$ depletions that we observe off Africa show no obvious evidence for the presence of this high- ${ }^{14} \mathrm{C}$ water mass further to the west. If any Pacific "return conveyor" ${ }^{14} \mathrm{C}$ signal exists there, it either does not outcrop at the surface or is swamped by the depleted Arabian Sea component.

\section{South China Sea}

$\Delta \mathrm{R}$ values for the South China Sea, plus some data for surrounding regions, are shown in Table 4 and Figures 2 and 3. With the exception of a single sample from Hong Kong discussed below, the South China Sea results cluster fairly well and show no obvious trends over time. The data indicate a mean 


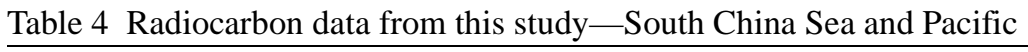

\begin{tabular}{|c|c|c|c|c|c|c|c|c|c|c|c|c|c|c|}
\hline $\begin{array}{l}\text { Sample codes } \\
\left(_{\text {CAMS\# })^{\mathrm{a}}}\right.\end{array}$ & Museum\# & $\begin{array}{l}\text { Species (b=bivalve, } \\
\mathrm{c}=\text { coral, } \mathrm{g}=\text { gastropod) }\end{array}$ & $\begin{array}{l}\text { Coll. } \\
\text { date }\end{array}$ & Location & $\begin{array}{l}\text { Lat } \\
\left({ }^{\circ} \mathrm{N}\right)\end{array}$ & $\begin{array}{l}\text { Long } \\
\left({ }^{\circ} \mathrm{E}\right)\end{array}$ & $\begin{array}{l}\delta^{13} \mathrm{C} \\
(\%)\end{array}$ & $\begin{array}{l}\Delta^{14} \mathrm{C} \\
(\% o)\end{array}$ & \pm & $\begin{array}{l}\Delta^{14} \mathrm{C} \\
\text { (Suess- }^{\text {Sues. }} \\
\text { corr. }\end{array}$ & $\begin{array}{l}{ }^{14} \mathrm{C} \text { age } \\
(\mathrm{BP})\end{array}$ & \pm & $\begin{array}{c}\text { Model } \\
\text { age } \\
\text { (BP) }\end{array}$ & $\Delta \mathrm{R}$ \\
\hline \multicolumn{15}{|c|}{ South/central South China Sea } \\
\hline 6568 & USNM-309839 & Cronia margariticola (b) & 1908 & $\begin{array}{l}\text { Mindoro Strait, } \\
\text { Philippines }\end{array}$ & 12.5 & 120.5 & 0 & -59.8 & 7.6 & -59.8 & 540 & 70 & 463 & 77 \\
\hline 6571 & USNM-309579 & Thais distinguenda $(\mathrm{g})$ & $1916^{\mathrm{c}}$ & Mona Is., Philippines & 12.0 & 120.0 & 0 & -45.6 & 7.7 & -45.6 & 410 & 70 & 463 & -53 \\
\hline 8695 & USNM-309529 & Gastropod & 1916 & $\begin{array}{l}\text { Janao Bay, Luzon, } \\
\text { Phillipines }\end{array}$ & 13.8 & 120.9 & 0 & -42.9 & 5.6 & -42.9 & 390 & 50 & 463 & -73 \\
\hline 49634 & & Porites (c) & 1905.5 & Xisha (Paracels) Is. & 16.7 & 112.3 & -2 & -50.8 & 4.3 & -50.8 & 460 & 40 & 463 & -3 \\
\hline 49635 & & Porites (c) & 1925.5 & Xisha (Paracels) Is. & 16.7 & 112.3 & -2 & -50.5 & 5.8 & -48.5 & 440 & 50 & 466 & -26 \\
\hline 49636 & & Porites (c) & 1948.5 & Xisha (Paracels) Is. & 16.7 & 112.3 & -2 & -65.2 & 6.3 & -56.2 & 540 & 60 & 482 & 58 \\
\hline 6570 & USNM-361252 & Thais hippocastaneum $(\mathrm{g})$ & 1923 & $\begin{array}{l}\text { Ko Ang Trang, } \\
\text { Thailand }\end{array}$ & 9.6 & 99.7 & 0 & -48.8 & 7.7 & -46.8 & 430 & 70 & 466 & -36 \\
\hline 3956 & MNHN-C31 & Gomphina aequilatera (b) & 1945 & Saigon & 10.8 & 106.8 & 0.3 & -52.8 & 6.7 & -44.8 & 440 & 56 & 480 & -40 \\
\hline 6572 & USNM-17039 & Cymia gradata $(\mathrm{b})$ & $1860^{c}$ & Singapore & 1.3 & 103.9 & 0 & -32.8 & 6.0 & -32.8 & 360 & 60 & 489 & -129 \\
\hline $3952+3961$ & MNHN-C27 & Marcia recens (b) & 1945 & Singapore & 2.9 & 103.8 & -2.4 & -53.7 & 4.5 & -45.7 & 448 & 38 & 480 & -32 \\
\hline \multicolumn{15}{|l|}{ Other } \\
\hline 6573 & USNM-36855 & Cronia margariticola (b) & $1884^{c}$ & Hong Kong SAR & 22.2 & 114.2 & 0 & -69.6 & 6.7 & -69.6 & 640 & 60 & 473 & 167 \\
\hline 8697 & USNM-217330 & Gastropod & $1920^{c}$ & Bo Hai Gulf, China ${ }^{\mathrm{d}}$ & ca. 39 & ca. 119 & 0 & -30.0 & 5.4 & -28.0 & 270 & 50 & 464 & -194 \\
\hline 8814 & USNM-706992 & Gastropod & 1927 & Tsingtao, China & 36.1 & 120.3 & 0 & -41.8 & 6.5 & -38.8 & 370 & 60 & 466 & -96 \\
\hline 6566 & USNM-312808 & Cronia margariticola (b) & $1925^{c}$ & SaBui Bay, S.Borneo & -3.0 & 111.5 & 0 & -62.0 & 7.1 & -60.0 & 540 & 70 & 466 & 74 \\
\hline 8694 & USNM-36238 & Gastropod & 1884 & Bonin Is. & 27.0 & 142.0 & 0 & -29.2 & 6.2 & -29.2 & 300 & 60 & 474 & -174 \\
\hline 8696 & USNM-309647 & Gastropod & 1903 & Guam & 13.5 & 144.8 & 0 & -51.6 & 5.5 & -51.6 & 470 & 50 & 465 & 5 \\
\hline
\end{tabular}

${ }^{\mathrm{a}}$ CAMS = Center for AMS, LLNL; MNHN = Museum National d'Histoire Naturelle; USNM = National Museum of Natural History, Smithsonian Institution; H = Hong Kong Museum of History.

${ }^{b}$ Estimated marine fossil fuel (Suess) effect, per mil: 1959: $-16 \pm 4 ; 1952:-10 \pm 2 ; 1949$ : $-9 \pm 3 ; 1945:-8 \pm 2 ; 1925:-2 \pm 2$; pre-1920: ca. zero.

${ }^{\mathrm{c} C o l l e c t e d ~ e a r l i e r, ~ a s s u m e d ~ d a t e ~ f o r ~ c a l c u l a t i o n ~}$

${ }^{\mathrm{d}}$ Location approximate 
Table 4 Radiocarbon data from this study —-South China Sea and Pacific (Continued) ${ }^{\mathrm{a}}$

\begin{tabular}{|c|c|c|c|c|c|c|c|c|c|c|c|}
\hline $\begin{array}{l}\text { Sample codes } \\
\text { CAMS\# }^{\mathrm{a}}\end{array}$ & Museum\# & $\begin{array}{l}\text { Species (b=bivalve, } \\
\mathrm{c}=\text { coral, } \mathrm{g}=\text { gastropod) }\end{array}$ & $\begin{array}{l}\text { Coll. } \\
\text { date }\end{array}$ & Location & $\begin{array}{l}\text { Lat } \\
\left({ }^{\circ} \mathrm{N}\right)\end{array}$ & $\begin{array}{l}\text { Long } \\
\left({ }^{\circ} \mathrm{E}\right)\end{array}$ & $\begin{array}{l}\delta^{13} \mathrm{C} \\
(\% o)\end{array}$ & $\begin{array}{l}\Delta^{14} \mathrm{C} \\
(\% o)\end{array}$ & \pm & $\begin{array}{l}{ }^{14} \mathrm{C} \text { age } \\
(\mathrm{BP})\end{array}$ & \pm \\
\hline \multicolumn{12}{|l|}{ Post-bomb data } \\
\hline \multicolumn{12}{|l|}{ Hong Kong } \\
\hline 46198 & H-64.3.52 & Bursa rana $(\mathrm{g})$ & 1955 & $\begin{array}{l}\text { Ap Lei Chau, Hong } \\
\text { Kong SAR }\end{array}$ & 22.2 & 114.2 & 0 & -32.9 & 4.4 & 260 & 40 \\
\hline 46200 & H-64.3.73 & Murex tribulus $(\mathrm{g})$ & 1956 & $\begin{array}{l}\text { Ap Lei Chau, Hong } \\
\text { Kong SAR }\end{array}$ & 22.2 & 114.2 & 0 & -32.4 & 4.4 & 260 & 40 \\
\hline 46201 & H-64.3.62 & Cypraea errones $(\mathrm{g})$ & 1957 & $\begin{array}{l}\text { Port Shelter, Hong } \\
\text { Kong SAR }\end{array}$ & 22.4 & 114.3 & 0 & -45.8 & 4.4 & 370 & 40 \\
\hline 46202 & H-64.3.80 & Columbella versiculor $(\mathrm{g})$ & 1957 & $\begin{array}{l}\text { Port Shelter, Hong } \\
\text { Kong SAR }\end{array}$ & 22.4 & 114.3 & 0 & -28.6 & 4.4 & 230 & 40 \\
\hline 46578 & H-64.3.367 & Clithon ovalaniensis (g) & 1958 & $\begin{array}{l}\text { Pearl Bay, Hong } \\
\text { Kong SAR }\end{array}$ & 22.5 & 114.3 & 0 & -34.0 & 3.6 & 270 & 40 \\
\hline 46579 & H-64.3.169 & Siphonaria japonica (g) & 1959 & $\begin{array}{l}\text { Ap Lei Chau, Hong } \\
\text { Kong SAR }\end{array}$ & 22.2 & 114.2 & 0 & -30.9 & 4.5 & 240 & 40 \\
\hline 46580 & H-64.3.614 & Littorina scabra $(\mathrm{g})$ & 1960 & $\begin{array}{l}\text { High Is., Hong } \\
\text { Kong SAR }\end{array}$ & 22.4 & 114.3 & 0 & 16.4 & 4.7 & > Modern & \\
\hline 46203 & H-64.3.624 & Ostrea crenulifera (b) & 1961 & $\begin{array}{l}\text { NW Mirs Bay, } \\
\text { Hong Kong SAR }\end{array}$ & 22.5 & 114.3 & 0 & -11.6 & 6.7 & 80 & 60 \\
\hline \multicolumn{12}{|c|}{ South/central South China Sea } \\
\hline 53108 & & Porites $(\mathrm{c})$ & 1955.4 & Xisha (Paracels) Is. & 16.7 & 112.3 & -1.6 & -54.9 & 4.0 & 450 & 40 \\
\hline 53109 & & Porites (c) & 1955.7 & Xisha (Paracels) Is. & 16.7 & 112.3 & -1.8 & -61.4 & 4.1 & 500 & 40 \\
\hline 53110 & & Porites $(\mathrm{c})$ & 1956.4 & Xisha (Paracels) Is. & 16.7 & 112.3 & -1.0 & -58.4 & 3.9 & 480 & 40 \\
\hline 53111 & & Porites $(\mathrm{c})$ & 1956.7 & Xisha (Paracels) Is. & 16.7 & 112.3 & -3.2 & -48.2 & 3.9 & 390 & 40 \\
\hline 53112 & & Porites $(\mathrm{c})$ & 1957.4 & Xisha (Paracels) Is. & 16.7 & 112.3 & -3.0 & -41.3 & 4.2 & 330 & 40 \\
\hline 53113 & & Porites $(\mathrm{c})$ & 1957.7 & Xisha (Paracels) Is. & 16.7 & 112.3 & -1.0 & -39.1 & 5.0 & 310 & 50 \\
\hline
\end{tabular}

${ }^{a}$ See previous page for footnotes. 
$\Delta \mathrm{R}$ and standard error $(\sigma / \sqrt{\mathrm{N}}, \mathrm{N}=10)$ of $-25 \pm 20$ years for the south/central part of the Sea. $\Delta \mathrm{R}$ values for the western Pacific and the eastern coast of China are even lower.

Like the Indian Ocean, the South China Sea circulation is strongly influenced by seasonal monsoons (Tchernia 1980). The winter monsoon drives a southwesterly flow along the northern and western coasts, fed by Pacific and East China Sea waters from the east and north, delivering water south to the Indonesian Seaway and forming the western boundary of an anti-clockwise gyre circulating between Vietnam and the Philippines. In summer the circulation is reversed, and Indonesian waters from the south feed a broad northeasterly flow that covers most of the Sea.

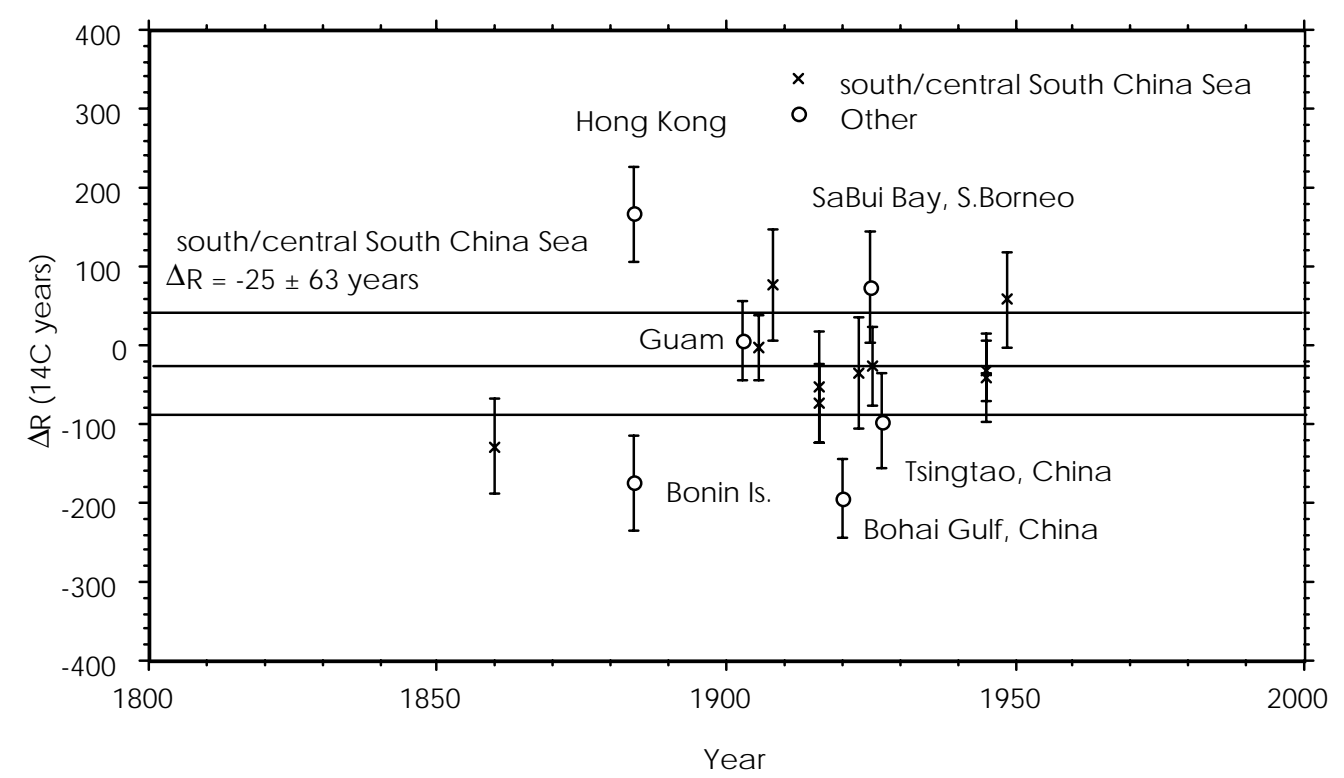

Figure $3 \Delta \mathrm{R}$ values for the south/central South China Sea and western Pacific, plotted against the year of collection. The Hong Kong result is high $(>2 \sigma)$ compared to the other South China Sea data.

The inflow from the north and east in winter is derived from the Kuroshio Current and its precursor, the Pacific North Equatorial Current (PNEC); and the low $\Delta \mathrm{R}$ values for the islands of Okinawa and Bonin (Konishi et al. 1982; this study) attest to the high levels of ${ }^{14} \mathrm{C}$ within these waters. The origin of the summer inflow from the south is more complex. A mixture of PNEC water retroflected south in the Mindinao Current east of the Philippines (Fine et al. 1994; Gordon 1995), together with Pacific South Equatorial Current (PSEC) waters intruding into the region northwest of New Guinea in summer (Tchernia 1980), feed currents flowing south to the Indonesian Seaway, then west and north. Equatorial upwelling reduces ${ }^{14} \mathrm{C}$ levels in the PSEC compared to those found in the waters further north, but ${ }^{14} \mathrm{C}$ values for the southern edge of this current system are nevertheless relatively high (Druffel and Griffin 1993, 1999). Thus, all of the source waters entering the South China Sea are rather well equilibrated with atmospheric ${ }^{14} \mathrm{C}$. Within the Sea itself, upwelling is restricted and ocean-atmosphere gas exchange enhanced, by the presence of broad shallow continental shelves and the low salinities (Levitus et al. 1994) that arise from high rainfall and surface runoff. Together, these influences produce the widespread low $\Delta \mathrm{R}$ values.

With one exception, the South China Sea samples are from the southern and central regions. A single sample from Hong Kong (collected pre-1884) gave a high $\Delta \mathrm{R}$ of $167 \pm 60$, a surprising result given 
the stronger influence of Pacific and East China Sea waters in the north and the low $\Delta \mathrm{R}$ values in those source regions. We were unable to find other pre-1950s specimens from the south China coast, but did obtain Hong Kong samples for 1955-1961. Note that even the earliest of these samples may not be truly prebomb, since there may have been early regional effects in the western Pacific from US thermonuclear tests in the Marshall Islands from 1953 onwards (Broecker et al. 1987).

Figure 4 shows $\Delta^{14} \mathrm{C}$ data (without Suess corrections) for the Hong Kong shells, samples from the south/central South China Sea, and Okinawa corals (Konishi et al. 1982). The Okinawa and south/ central South China Sea data are consistently offset over the entire period from 1915 to 1960, while the Hong Kong ${ }^{14} \mathrm{C}$ values from the late 1950s show large scatter, but generally lie within these two trend lines. On average, the Hong Kong values for 1955-56 are higher than those from farther south, corresponding to lower $\Delta \mathrm{R}$. On this basis, and given the uncertain collection date of the 19th century Hong Kong sample, we discount that result and suggest that $\Delta \mathrm{R}$ for the South China coast probably lies between the values of $-25 \pm 20$ for the waters to the south and $-149 \pm 7$ for Okinawa (Konishi et al. 1982). However, the true value will only be determined when pre-1950 samples become available.

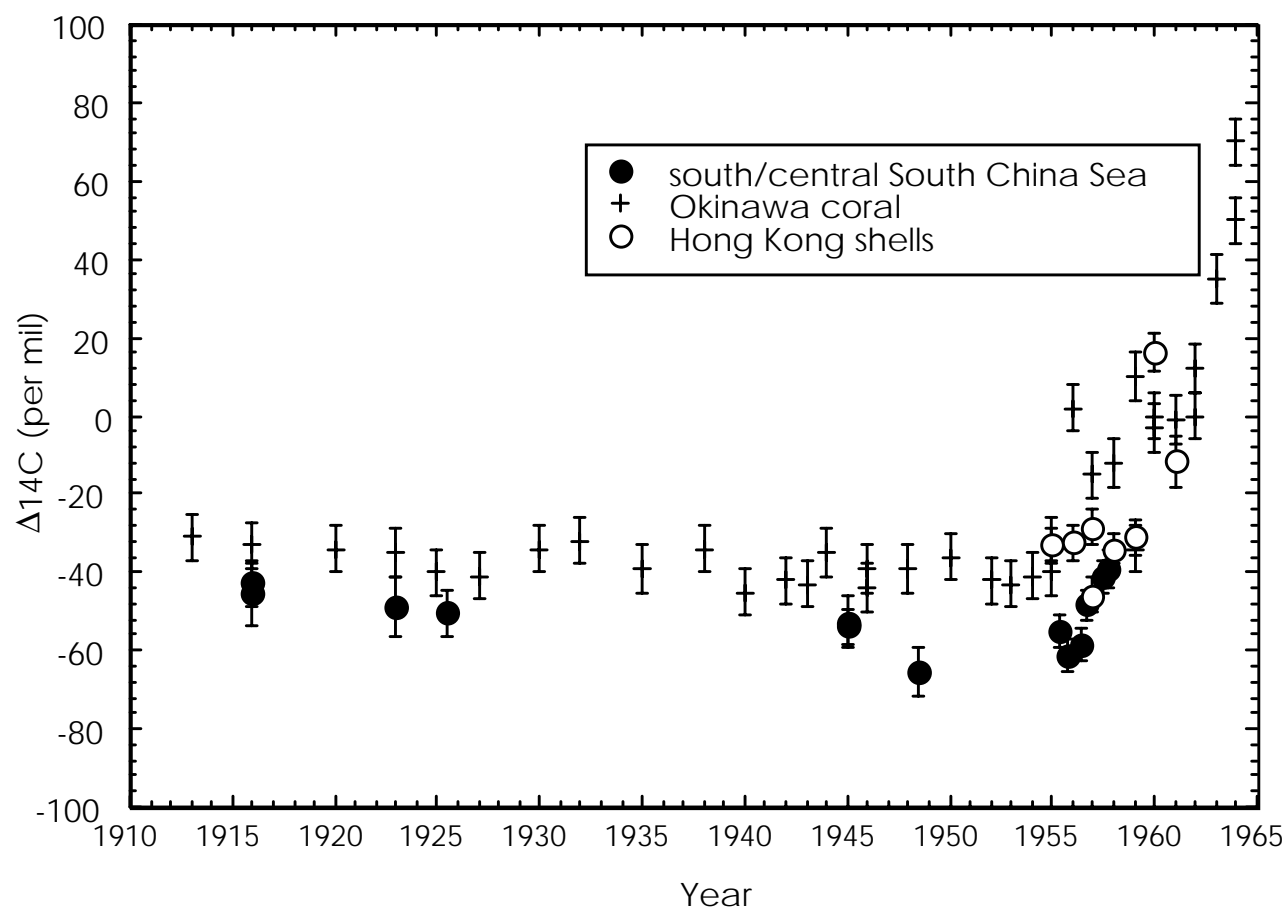

Figure $4 \Delta{ }^{14} \mathrm{C}$ values for the period 1910-1965, plotted without Suess correction. Okinawa values are consistently higher than those from the south/central South China Sea. Hong Kong data from the late 1950s generally fall between these two trends.

\section{CONCLUSIONS}

Surface waters over large areas of the western Indian Ocean are significantly influenced by Arabian Sea upwelling, with regional $\Delta \mathrm{R}$ mean values ranging from 140 to 205 years. These results contrast with data from southern Java and northern Australia which show $\Delta \mathrm{R}$ values of 50 years or less. This difference is explained by the presence of well-equilibrated water masses in the western Pacific, which flow into the eastern Indian Ocean via Torres Strait and the Indonesian Seaway. The South 
China Sea is also strongly influenced by these high- ${ }^{14} \mathrm{C}$ Pacific waters, and $\Delta \mathrm{R}$ values for the south/ central part of the Sea are close to zero. Post-bomb results for Hong Kong suggest that $\Delta \mathrm{R}$ values along the South China coast may be even lower.

\section{ACKNOWLEDGMENTS}

We thank Dr Jerry Harasewych of the Smithsonian Institution for assistance with sample selection, Joseph Ting of the Hong Kong Museum of History for making available his shell collection, and Dr Min Sun of the University of Hong Kong for developing the age model for the coral sample. This research was performed under the auspices of the US Department of Energy at Lawrence Livermore National Laboratory under contract W-7405-Eng-48. Co-author W W-S Y was supported by research grants from the University Grants Council of Hong Kong and the University of Hong Kong.

\section{REFERENCES}

Bard E, Arnold M, Toggweiler JR, Maurice P, Duplessy J-C. 1989 . Bomb ${ }^{14} \mathrm{C}$ in the Indian Ocean measured by accelerator mass spectrometry: oceanographic implications. Radiocarbon 31(3):510-22.

Bhushan R, Chakraborty S, Krishnaswami S. 1994. Physical Research Laboratory (Chemistry) radiocarbon date list I. Radiocarbon 36(2):251-6.

Bowman GM. 1985. Oceanic reservoir correction for marine radiocarbon dates from northwestern Australia. Australian Archaeology 20:58-67.

Broecker WS. 1963. ${ }^{14} \mathrm{C} /{ }^{12} \mathrm{C}$ ratios in surface ocean water. U.S. National Academy of Sciences, National Research Council publication 1075:138-49.

Broecker WS, Cember RP, Toggweiler JR, Trumbore SE, White J. 1987. Final Report on the Lamont-Doherty geological Observatory coral radioisotope project. DOE/EV/10041C-1 (unpublished).

Cember R. 1989. Bomb radiocarbon in the Red Sea: a medium-scale gas exchange experiment. Journal of Geophysical Research 94:2111-23.

Church JA, Cresswell G, Godfrey JS. 1989. The Leeuwin Current. In: Neshyba SJ, Mooers ChNK, Smith RL, Barber RT, editors. Poleward flow along eastern ocean boundaries. Coastal and Estuarine Studies 34. New York: Springer-Verlag. p 230-54.

Delibrias G. 1980. Carbon-14 in the Southern Ocean. Radiocarbon 22(3):684-92.

Druffel, ERM. 1997. Pulses of rapid variation in the North Atlantic surface ocean during the past century. Science 275:1454-7.

Druffel ERM, Griffin S. 1993. Large variations of surface ocean radiocarbon: evidence of circulation changes in the southwestern Pacific. Journal of Geophysical Research 98: 20249-59.

Druffel ERM, Griffin S. 1999. Variability of surface ocean radiocarbon and stable isotopes in the southwestern Pacific. Journal of Geophysical Research 104: 23607-13.

Druffel ERM, Suess H. 1983. On the radiocarbon record in banded corals. Journal of Geophysical Research 88: 1271-80.
Dutta K, Bhushan K, Somayajulu BLK. 2001. $\Delta$ R correction values for the northern Indian Ocean. Radiocarbon 43(2):483-8.

Dye T. 1995. Apparent ages of marine shells: implications for archaeological dating in Hawai' $i$. Radiocarbon 36(1):51-7.

Fieux M, Andrie C, Delecluse P, Ilahude AG, Kartavtseff A, Mantisi F, Molcard R, Swallow JC. 1994. Measurements within the Pacific-Indian oceans flowthrough region. Deep Sea Research 41: 1091-130.

Fieux M, Andrie C, Charriaud E, Ilahude AG, Metzel N, Molcard R, Swallow JC. 1996. Hydrological and chlorofluoromethane measurements of the Indonesian flowthrough entering the Indian Ocean. Journal of Geophysical Research 101:12433-54.

Fine RA, Lukas R, Bingham FM, Warner MJ, Gammon RH. 1994. The western equatorial Pacific: a water mass crossroads. Journal of Geophysical Research 99: 25063-80.

Ganachaud A, Wunsch C. 2000. Improved estimates of global ocean circulation, heat transport and mixing from hydrographic data. Nature 408:453-7.

Gentilli J. 1972. Thermal anomalies in the Eastern indian Ocean. Nature Physical Science 238:93-5.

Gillespie R. 1977. Sydney University natural radiocarbon measurements IV. Radiocarbon 19(1):101-10.

Gordon AL. 1986. Interocean exchange of themocline water. Journal of Geophysical Research 91: 5037-46.

Gordon AL. 1995. When is "appearance" reality? Indonesian flowthrough is primarily derived from N. Pacific water masses. Journal of Physical Oceanography 25:1560-7.

Ingram L, Southon JR. 1996. Reservoir ages in eastern Pacific coastal and estuarine water. Radiocarbon 38(3):573-82.

JGR. 1996. Special session: Pacific low-latitude western boundary currents and the Indonesian flowthrough. Journal of Geophysical Research 101:12209-488.

Konishi K, T.Tanaka T, Sakanoue M. 1982. Secular variation of radiocarbon concentrations in seawater: Sclerochronological approach. In: Gomez ED, editor. Pro- 
ceedings of the Fourth International Coral Reef Symposium. Volume 1. Manila: Marine Science Center, University of the Phillipines. p 181-5.

Levitus S, Burgett R, Boyer TP. 1994. World ocean atlas volume 3: salinity. NOAA Altas NESDIS 3. Washington DC: US Department of Commerce.

Loyd DH, Vogel JS, Trumbore S. 1991. Lithium contamination in AMS measurements of ${ }^{14} \mathrm{C}$. Radiocarbon 33(3):297-301.

Michida Y, Yoritaki H. 1996. Surface currents in the area of the Indo-Pacific flowthrough and in the tropical Indian Ocean. Journal of Geophysical Research 101: 12475-82.

Rhodes EG, Polach HA, Thom BG, Wilson SR. 1980. Age structure of Holocene coastal sediments: Gulf of Carpentaria, Australia. Radiocarbon 22(3):718-27.

Schmitz WJ. 1995. On the interbasin-scale thermohaline circulation. Reviews of Geophysics 33:151-73.

Schott F, Swallow JC, Fieux M. 1990. The Somali Current at the equator: annual cycle of currents and transports in the upper $1000 \mathrm{~m}$ and connection to neighbouring latitudes. Deep Sea Research 37: 11825-48.

Southon JR, Caffee MW, Davis JC, Moore TL, Proctor ID, Schumacher B, Vogel JS. 1990. The new LLNL AMS spectrometer. Nuclear Instruments and Methods in Physics Research B52:301-5.

Stramma L, Lutjeharms JRE. 1997. The flow field of the subtropical gyre of the South Indian Ocean. Journal of Geophysical Research 102:5513-30.

Stuiver M, Polach, H. 1977. Reporting of ${ }^{14} \mathrm{C}$ data. Radiocarbon 19(3):355-63.

Stuiver M, Braziunas TF. 1993. Modeling atmospheric ${ }^{14} \mathrm{C}$ influences and ${ }^{14} \mathrm{C}$ ages of marine samples to 10,000 BC. Radiocarbon 35(1):137-89.

Stuiver M, Ostlund, HG. 1983. GEOSECS Indian Ocean and Mediterranean radiocarbon. Radiocarbon 25(1): $1-29$.

Stuiver M, Pearson GW, Braziunas TF. 1986. Radiocarbon age calibration of marine samples back to 9000 cal BP. Radiocarbon 28(2B):980-1021.

Stuiver M, Reimer PJ, Braziunas TF. 1998. High-precision radiocarbon age calibration for terrestrial and marine samples. Radiocarbon 40(3):1127-51. (Data available on the Internet at http://www.calib.org/marine).

Swallow JC. 1984. Some aspects of the physical oceanography of the Indian Ocean. Deep Sea Research 31: 639-50.

Tchernia P. 1980. Descriptive regional oceanography. Pergamon, Oxford University Press.

Toggweiler R, Dixon K, Broecker WS. 1991. The Peru upwelling and the ventilation of the South Pacific thermocline. Journal of Geophysical Research 96:2046797.

Toole JM, Warren BA 1993. A hydrographic section across the subtropical South Indian Ocean, Deep Sea Research 40:1973-2019.

Vogel JS, Nelson DE, Southon JR. 1987. ${ }^{14} \mathrm{C}$ background levels in an AMS system. Radiocarbon 29(3):323-33.

von Rad U, Schaff M, Michels KH, Berger WH, Siricko F. 1999. A 5000-yr record of climate change in varved sediments from the oxygen minimum zone off Pakistan, northeastern Arabian Sea. Quaternary Research 51:39-53.

Wrytki K. 1973. Physical oceanography of the Indian Ocean. In: Zeitschel B, editor. The biology of the Indian Ocean. New York: Springer-Verlag. p 18-36.

You Y. 1997. Seasonal variations of themocline circulation and ventilation in the Indian Ocean. Journal of Geophysical Research 102: 10391-422. 